\title{
A Study on the Feasibility of Using Leachate of Open Dumps as Moisture in Composting Municipal Solid Waste
}

\author{
Jayaweera J.A.S.* and Bandara N.J.G.J.
}

\author{
${ }^{I}$ Department of Forestry and Environmental Science, Faculty of Applied Sciences, University of Sri \\ Jayawardenepura, Nugegoda, Sri Lanka. \\ *anu.asj75@yahoo.com
}

\begin{abstract}
With the increasing population and development of industries, solid waste disposal has become a major issue in Sri Lanka. The most common type of disposal is open dumping in urban areas which causes many environmental and social impacts. Especially generating leachate from open dumps has become a severe problem. Viable options for acceptable solid waste management practices in economically developing countries include minimization, recycling, composting, incineration, and sanitary landfilling. Composting is the option that, with few exceptions, best fits within the limited resources available in developing countries. Composing has some advantages such as lower equipment and operating costs, woks in harmony with the environment, and results a useful product.

This study has been carried out in the Mithotamulla open dumping site located in Western Province, Sri Lanka in the intension of studying the feasibility of using leachate of open dumps as moisture in composting Municipal Solid Waste.

This paper presents the section of the research which deals with the objective of analysing the composting process performance indicators such as $\mathrm{pH}, \mathrm{C} / \mathrm{N}$ ratio, temperature and total organic matter at usage of water and different dilutions of open dump leachate $(100 \%, 75 \%$, $50 \%, 25 \%$ and $15 \%$ - by volume) on compost piles as moisture and studying the physical, chemical and biological parameters of used open dump leachate and water in composting.

Biodegradable part of the receiving MSW to the Mithotamulla dumping site was separated and mixed thoroughly in order to obtain preferable raw material for composting. A set of composting piles containing six piles were made in similar dimensions. Water was added to the first file(control pile) as moisture and a concentration series $(100 \%, 75 \%, 50 \%, 25 \%$ and $15 \%$ by volume) made from open dump leachate was added to the each of the other remaining five piles respectively as sufficient to maintain the moisture content $60 \%$ in first six weeks and as $40 \%$ in next two weeks. Pile turning was done manually in every seven days and the process was monitored in the active phase of the composting process; eight weeks period.
\end{abstract}

Temperature values and pile dimensions of each pile were recorded every day and other important composting performance indicators; $\mathrm{pH}$, Total Nitrogen, Total Organic Carbon, Total organic matter were analysed weekly. $\mathrm{C} / \mathrm{N}$ ratio was calculated using obtained values weekly. Samples were taken from nine symmetrical points in various depths in each pile and finally three composite samples were made from each pile for analysis in each week. Environmental temperature was also recorded every day. 
Leachate sample collection was conducted during dry season of year 2013. All leachate samples were collected from the collected leachate in the stream around the open dumping site in Mithotamulla and were stored at $4{ }^{\circ} \mathrm{C}$ for until used for analysis. Leachate analysis was carried out four times in the research period as 2 months before composting, at the beginning of composting process, at the $4^{\text {th }}$ week and at the $8^{\text {th }}$ week of composting process. All the leachate samples were analysed for following physical as well as chemical parameters included temperature, $\mathrm{pH}$, Electrical Conductivity, Total Dissolved Solids, Total Suspended Solids, Total Solids, Chloride, $\mathrm{Ca}^{2+}$ content, $\mathrm{Mg}^{2+}$ content, BOD, COD, Sulfate, Total organic matter, heavy metals and E.coli content. Some of the parameters of used water as moisture to the control pile were also measured periodically similar to the leachate analysis when possible.

According to the obtained results, it can be concluded that leachate from open dumping site contains higher amount of inorganic as well as organic component which may cause contamination of groundwater as well as surface water and also soil. Mainly BOD, COD, heavy metal contents and E.coli content is very much higher than the permitted levels for the disposal of landfill leachate.

Through the results of analysing the behaviour of process performance indicators of composting, the highest percentage volume reduction $(61.17 \%)$ of pile was recorded in the usage of $100 \%$ open dump leachate as moisture. And the highest reduction $\mathrm{C} / \mathrm{N}$ ratio and TOM were recorded from the pile which used $50 \%$ and $75 \%$ leachate dilutions respectively. Temperature values of control, $100 \%$ and $25 \%$ piles were in the desirable range for thermophilic bacteria. And those of other piles have exceeded it.

Keywords: Municipal Solid Waste (MSW), Composting, Open dumping, Leachate, Process performance indicators of composting, Compost piles 